\title{
The pattern of vancomycin, gentamycin, and meropenem prescriptions for the inpatients of a regional public hospital in Yogyakarta, Indonesia
}

\author{
Mutiara Herawati $^{1}$, Mir-a Kemila$^{2}$, Putri Anggriani ${ }^{1}$, Nur Mardhiyah ${ }^{1}$, Siti Maulida ${ }^{1}$
}

${ }^{1}$ Department of Pharmacy, Faculty of Science and Mathematics, Universitas Islam Indonesia, Yogyakarta

${ }^{2}$ Pharmacy Department, JIH Hospital, Yogyakarta, Indonesia

*Corresponding author: mutiara.herawati@uii.ac.id

\begin{abstract}
Background: The mechanism of action of gentamycin is inhibiting protein synthesis inside bacteria. Meropenem and vancomycin have the same mode of action that inhibit bacterial cell wall activity. Antibiotic resistance occurs when antibiotic use does not follow the guidelines. Therefore, this study aims to determine how vancomycin, gentamycin, and meropenem are prescribed in a regional public hospital.

Objective: This study aimed to evaluate the prescription of vancomycin, gentamycin, and meropenem in Yogyakarta Regional Public Hospital in 2017.

Methods: This research employed a descriptive analysis with a cross-sectional design. The study was conducted to describe the profiles of vancomycin, gentamycin, and meropenem utilization. Data collection was performed retrospectively using patients' medical record data including the diagnosis, dosage, and duration of administration.

Results: The study showed that the total number of patients who received aminoglycoside: meropenem: vancomycin antibiotics in 2017 and met the research criteria was 6:8:24. According to the diagnosis, gentamycin was used for post-operation (75\%), then sepsis and encephalitis. Meropenem was used for sepsis with a percentage of $67 \%$ while vancomycin was for endocarditis, intraabdominal, MRSA, cellulitis, pneumonia, and sepsis. Based on the appropriate dosage in the guidelines, the prescribing of gentamycin and meropenem resulted in $100 \%$ properness and $69.23 \%$ for vancomycin. For the duration of appropriate utilization, it was found that the most prolonged use was in patients given meropenem for 29 days, and the fastest use was a day for patients using vancomycin.

Conclusion: Vancomycin, gentamycin, and meropenem had the appropriate dosage. However, discrepancies were still found in the indication and duration of the treatment using these antibiotics.

Keywords: Vancomycin, gentamycin, meropenem, antibiotics
\end{abstract}

\section{Introduction}

Infectious diseases are among the leading causes of death in developing countries. One of the developing countries is Indonesia (WHO, 2015a). Antibiotics to treat and prevent infectious diseases caused by bacteria are widely used globally, and $65 \%$ of the patients in 12 countries used antibiotics for six months. As many as $81 \%$ said they were prescribed or given antibiotics by doctors or nurses (average between countries: 56\% - 93\%). As many as 93\% said they received antibiotics from pharmacies or drugstores (average between countries: 83\% - 97 \%) (WHO, 2015b).

Inappropriate prescribing of antibiotics leads to resistance. In addition, the length of administration and excessive use elevate the risk of such resistance (Bisht, et al., 2009). Antibiotic resistance has an impact on the increasing medical costs and mortality (WHO, 2017).

Vancomycin, gentamicin, and meropenem are antibiotics that doctors prescribe to treat severe infections. The use of these antibiotics must be monitored to minimize antibiotic resistance. 
137 | Herawati, M., et al. /Jurnal Ilmiah Farmasi (Scientific Journal of Pharmacy) Special Edition 2022, 136146

Vancomycin is of the glycopeptide class that works by inhibiting bacterial cell wall synthesis. Vancomycin is used to treat serious infections caused by gram-positive bacteria, such as S. aureus and S. epidermidis that are resistant to methicillin or Methicillin-Resistant Staphylococcus Aureus (MRSA), S. pneumonia, S. pyogenes, and Viridans Streptococci (Brunton et al., 2008). In addition, vancomycin can also be used for colitis, enterocolitis, endophthalmitis, hospital-acquired pneumonia, meningitis, and prophylaxis in surgical procedures (Aberg et al., 2009).

Vancomycin is an antibiotic of which the use must be restricted. Its use is based on the guidelines or approval from the Antibiotic Resistance Control Committee (PPRA) in hospitals (Fauzia, 2015). In 2010, Vancomycin-Resistant Staphylococcus Aureus (VRSA) was found in 10 of 64 isolates (15.6\%) of the stethoscope membrane in a study of the resistance of Staphylococcus aureus to vancomycin antibiotics at Margono Soekarjo Hospital in Purwokerto (Anjarwati, 2010).

Gentamicin is a group of aminoglycosides. It has a mechanism of action by inhibiting protein synthesis in bacterial cells. The aminoglycoside group interferes with protein synthesis by binding to the 30S ribosomal subunit, thus inhibiting bacterial cell protein formation. Because of the narrow therapeutic range, aminoglycosides exert a bactericidal effect at high serum concentrations. These antibiotics also show a post-antibiotic impact, which means that the bactericidal effect continues even after serum levels drop below the level considered to be therapeutic (Bruce \& Hicks, 2011). Meanwhile, the antibiotic resistance data show a 70\% gentamicin resistance pattern (Nurmala et al., 2015).

Meropenem is an antibiotic from the carbapenem group included in the list of antibiotics the use of which must be limited. Meropenem antibiotics have a broad-spectrum activity, so they are frequently used to treat serious infections caused by bacteria that are resistant to previous antibiotics. Sometimes this antibiotic becomes the last choice for several infections (Halim et al., 2017). However, some specific criteria limit the use of meropenem in patients. It can only be given to patients infected with ESBL bacteria and to those with prophylactic surgery for the heart (KeMenKes RI, 2017). At Dr. Cipto Mangunkusumo Hospital, it was known that 50.5\% of Acinetobacter baumanii bacteria isolated from ICU patients were resistant to carbapenem, and from 24 isolates of $A$. baumanii bacteria isolated from neonates in NICU, $82 \%$ of the bacteria were found to be resistant to Carbapenem (Karuniawati, 2013; Tjoa, 2013).

This research was conducted in one of the regional general hospitals in Yogyakarta at the final level of health insurance facility in Indonesia (BPJS) to examine the use of Vancomycin, Gentamicin, and Meropenem antibiotics. The use of these antibiotics were observed based on the diagnosis, dosage, and duration.

Seminar Nasional Asosiasi Perguruan Tinggi Farmasi Indonesia (APTFI) III-Tantangan Pandemik (covid-19) dalam pembelajaran dan penelitian kefarmasian 16-20 Agustus 2021 (Virtual Conference) 
138 | Herawati, M., et al. /Jurnal Ilmiah Farmasi (Scientific Journal of Pharmacy) Special Edition 2022, 136146

\section{Method}

\subsection{Research subjects}

This study was a descriptive observational study with a cross-sectional study design in one of the public hospitals in Yogyakarta. Patients were eligible to participate in this study if they were prescribed vancomycin, gentamicin, or meropenem. Data was collected from the patient's medical records in 2017.

\subsection{Data collection}

The data collected consisted of the patient's name, gender, age, diagnosis, dosage, duration of use, and patient's laboratory data. Meanwhile, the data source used was the patient's medical record during 2014-2017. All data was collected using a data collection sheet. This data sheet was proceeded with a research form or research tool. The duration of information was stored by following the length of data storage at the hospital where the study was conducted.

\subsection{Statistical analysis}

The data obtained were then presented in the form of reports and tables to identify the patterns of use of vancomycin, gentamycin, and meropenem antibiotics at the hospital.

\section{Results and discussion}

Thirty-eight patients received vancomycin or gentamicin, or meropenem prescribing. Of these patients, six received vancomycin, eight took gentamicin, and 24 were given meropenem. Vancomycin and meropenem were administered BID or in three divided doses, and gentamicin was administered once daily, BID, or in three divided doses. The mean (range) duration of treatment was 6.8 days ( 1 to 12 days) in the vancomycin group, six days (4-10 days) in the gentamicin group, and nine days ( 2 to 29 days) in the meropenem group (Table 1 ).

Table 1. Demographic characteristics of the evaluated patients

\begin{tabular}{lccc}
\hline \multicolumn{1}{c}{ Characteristic } & Vancomycin & Gentamicin & Meropenem \\
\cline { 2 - 4 } & \multicolumn{1}{c}{ patient (n) } & \\
\hline No. of patients & $6 / 2$ & 8 & 24 \\
Sex (No. of males/No. of females) & $59(21-60)$ & $4 / 4$ & $14 / 10$ \\
Mean age, years (range) & $6.8(1-12)$ & $6(23-69)$ & $52(21-77)$ \\
Mean treatment duration, days (range) & & & $9(2-29)$ \\
\hline No. of patients with an infectious disease & 1 & & \\
Endocarditis infection & 1 & & \\
Intraabdominal sepsis & 1 & & \\
MRSA & 1 & & \\
Cellulitis & 1 & & \\
Pneumonia & 1 & 6 & \\
Sepsis & & & \\
Post Operation & & & \\
\hline
\end{tabular}

Seminar Nasional Asosiasi Perguruan Tinggi Farmasi Indonesia (APTFI) III-Tantangan Pandemik (covid-19) dalam pembelajaran dan penelitian kefarmasian 16-20 Agustus 2021 (Virtual Conference) 
139 | Herawati, M., et al. /Jurnal Ilmiah Farmasi (Scientific Journal of Pharmacy) Special Edition 2022, 136146

\begin{tabular}{|c|c|c|}
\hline \multirow{2}{*}{ Characteristic } & Vancomycin & Meropenem \\
\hline & \multicolumn{2}{|l|}{ patient $(n)$} \\
\hline Encephalitis & 1 & \\
\hline Urinary Tract Infection & & 4 \\
\hline
\end{tabular}

Table 1 shows that male patients are more likely to be patients receiving antibiotic regimens. For example, in Balasubramanian's study, 2011, the prescribing pattern of antimicrobials in a tertiary care hospital was obtained from 16,121 prescriptions containing antibiotics, indicating that some antibiotics were more widely used among male patients (Balasubramanian et al., 2011).

The response of disease between men and women can be very different. Some factors can cause the risk of having an infection. One crucial factor is differences in lifestyle and the different levels of immunity to disease between men and women. The exemption is influenced by sex hormones and the presence of other expressions of the X-chromosome gene encoded in the immune response to pathogens, as in autoimmunity, including multiple autoimmune diseases, with women having a percentage of $80 \%$. However, another study that reviews sex differences in parasitic infections shows that men are more often affected by several parasites, including amoebic liver abscesses that occur to more than $80 \%$ of them. Therefore, the magnitude of the risk of infection between men and women can differ depending on the type of pathogen that attacks the patient (Van Lunzen \& Altfeld, 2014).

Table 1 shows the mean age of $\geq 40$ years. Productive age into geriatrics is the age group that receives the most antibiotics due to decreased functions of the organs and immune system. Therefore, this group is more at risk and vulnerable to bacteria that cause infections. Vancomycin is thus minimally administered because caution is needed in prescribing it. Table 1 shows the condition of a severe disease given vancomycin. In the Gentamicin group, it was seen that the most use was found in the patient's condition after undergoing surgery. In contrast, the use of meropenem was mostly in the situation of sepsis.

Vancomycin can be given to patients with a diagnosis of infective endocarditis if they are unable to tolerate penicillin or ceftriaxone administration. Vancomycin can also be given to patients diagnosed with infective endocarditis as empirical therapy until the microbiological culture tests are obtained (Baddour et al., 2015). Vancomycin can be used alone for infective endocarditis or, if needed, can be given in combination with the aminoglycoside class (Baddour et al., 2015; Dipiro et al., 2008).

Vancomycin can be administered for intraabdominal sepsis caused by Enterococcus faecalis bacteria, ampicillin-resistant enterococci, and MRSA. Vancomycin can also be given as 
140 | Herawati, M., et al. /Jurnal Ilmiah Farmasi (Scientific Journal of Pharmacy) Special Edition 2022, 136146

empirical therapy for intraabdominal sepsis and can be combined with cefepime, ciprofloxacin, doripenem, imipenem/cilastatin, levofloxacin, meropenem, or piperacillin/tazobactam (Solomkin et al., 2009).

The guidelines from the American Thoracic Society and Infectious Society Disease of America recommend that empirical therapy for Hospital Acquired Pneumonia (HAP) in patients at risk of multidrug-resistance should include treatment for Methicillin-Resistant Staphylococcus aureus (MRSA), namely vancomycin. Hospital-Acquired Pneumonia (HAP) or nosocomial pneumonia occurs after a patient is hospitalized for 48 hours (ATS Board, 2005; Patanwala et al., 2009).

Gentamycin antibiotics are effective against gram-negative bacteria which also often produce septic shock compared to gram-positive organisms. Gram-negative sepsis also results in a higher mortality rate compared to sepsis from other groups of organisms (Dipiro et al., 2008).

Based on the literature on the management of aminoglycosides in the intensive care unit, gentamycin distribution to the lung tissue is not optimal. Infected airways, especially alveoli, multiply and cause pneumonia (Radigan et al., 2010). As a result, gentamycin does not help treat pneumonia due to anaerobic bacteria or S. pneumonia, which is a cause of pneumonia obtained in public (CAP). Meanwhile, in hospital-acquired pneumonia (HAP), where gram-negative aerobic organisms are the most common cause, gentamycin is recommended with $\beta$-lactam antibiotics as standard therapy (Brunton et al., 2011).

The use of gentamycin as surgical prophylaxis is not the primary recommendation. In the antibiotic selection guide from IDSA 2013, it is mentioned that the recommended antibiotic is cefazolin, with the most level of evidence A and B in most surgical procedures. In some cases, ampicillin-sulbactam, ceftriaxone, or a combination with metronidazole can be used (CDK, 2014). Antibiotics in the Gentamycin group, according to the clinical practice guidelines for antimicrobial prophylaxis in surgery, can also be given in several surgical procedures, especially as an alternative for patients who are allergic to antibiotics but in use with other antibiotics such as clindamycin or vancomycin. In patients undergoing antibiotic surgical procedures, gentamycin used as prophylaxis is generally administered with a recommended dose of $5 \mathrm{mg} / \mathrm{kg}$ in adult patients and $2.5 \mathrm{mg} / \mathrm{kg}$ in pediatric patients (Bratzler et al., 2013).

Meropenem is an antibiotic often prescribed to patients with sepsis because sepsis is a disease with a high risk of complications and death. Therefore, the selection of antibiotics with a broad antibacterial activity such as meropenem is appropriate for treating severe infections in critically ill patients. In a previous study, Carbapenem becomes the second class of antibiotics most widely used to treat sepsis (Díaz-Martín et al., 2012).

Seminar Nasional Asosiasi Perguruan Tinggi Farmasi Indonesia (APTFI) III-Tantangan Pandemik (covid-19) dalam pembelajaran dan penelitian kefarmasian 16-20 Agustus 2021 (Virtual Conference) 
141 | Herawati, M., et al. /Jurnal Ilmiah Farmasi (Scientific Journal of Pharmacy) Special Edition 2022, 136146

Meropenem is a broad-spectrum antibiotic that is very potent against Enterobacteriaceae, Pseudomonas spp, Acinetobacter spp, H. influenza, and anaerobic bacteria and can fight resistant organisms that cause severe nosocomial infections. A previous study has reported that meropenem has demonstrated its efficacy as the first-line treatment for respiratory infections and nosocomial pneumonia in ICUs with low mortality (Santos et al., 2001). According to the Handbook of Pharmacotherapy, patients diagnosed with bronchitis can be given Carbapenem class if the disease has reached stage 4 (Dipiro et al., 2009).

The Journal of Infectious Disease Society of America (IDSA) stated that meropenem is one of the beta-lactam antibiotics used as empirical therapy to treat CAP caused by gram-negative bacilli such as P. aeruginosa and Enterobacteriaceae, combined with ciprofloxacin or levofloxacin (Mandell et al., 2007; Gupta et al., 2012). The recommended dosage of meropenem given to CAP patients is 1 gram every 8 hours with infusion for 3 hours (Gupta et al., 2012). In patients diagnosed with HospitalAcquired Pneumonia (HAP), the bacteria that infect patients are unknown because there is no examination of bacterial culture. According to the IDSA guidelines: Management of Adults with HAP/CAP, patients diagnosed with HAP that are not at risk indicated by MRSA bacteria and not at high risk of death can be given meropenem empirically at a dose of 1 gram every 8 hours IV (Kalil et al., 2016).

Meropenem antibiotics can be given to patients with urinary tract infections if the patients have a severe infection and are susceptible to bacterial infection with Extended-Spectrum BetaLactamase (ESBL), to patients with Pseudomonas or multi-drug resistance risk factors, or to patients with severe infections due to unknown pathogens (Anonymous, 2015; Gupta, 2017).

Table 2. Drug profile in patients receiving vancomycin or gentamicin or meropenem

\begin{tabular}{cccc}
\hline Drug Profile & Vancomycin & Gentamicin & Meropenem \\
\cline { 2 - 4 } & & patient (n) & \\
\hline Number of patients & 6 & 8 & 24 \\
\hline Drug Dosage & 1 & & \\
$500 \mathrm{mg} / 8$ hours & 1 & & \\
$500 \mathrm{mg} / 12$ hours & 4 & & \\
1 gram/12 hours & & 6 & \\
$80 \mathrm{mg} / 8$ hours & & 1 & 19 \\
$80 \mathrm{mg} / 12$ hours & & & 5 \\
$80 \mathrm{mg} / 24$ hours & & & \\
1 gram/8 hours & & 6 & 11 \\
1 gram/12 hours & 3 & 2 & 12 \\
\hline Duration & 3 & & \\
\hline 7 days & & & \\
\hline
\end{tabular}

Seminar Nasional Asosiasi Perguruan Tinggi Farmasi Indonesia (APTFI) III-Tantangan Pandemik (covid-19) dalam pembelajaran dan penelitian kefarmasian 16-20 Agustus 2021 (Virtual Conference) 
142 | Herawati, M., et al. /Jurnal Ilmiah Farmasi (Scientific Journal of Pharmacy) Special Edition 2022, 136146

An appropriate dosage is given based on the literature or existing guidelines, namely from the drug information handbook-100\% dosage compliance. The dosage given can depend on the patient's conditions, such as age, weight, dosage calculation, and other accompanying conditions.

The dosage of vancomycin for diagnosed infective endocarditis in patients was $500 \mathrm{mg}$ every 8 hours given intravenously. Based on the literature, the vancomycin dosage for infective endocarditis is $1000 \mathrm{mg}$ every 12 hours for patients with normal kidney conditions, whereas for patients with complications of kidney failure, the dosage should be adjusted to the patient's kidney function by calculating the creatinine clearance. Therefore, based on the literature on vancomycin use in patients with infective endocarditis, the dosage given was below the dosage listed in the literature or not following the literature (Vandecasteele \& De Vriese, 2010).

The vancomycin dosage received by patients diagnosed with intraabdominal sepsis was 1 g every 12 hours in a drip of $100 \mathrm{cc} \mathrm{NaCl}$, which was used up in 1 hour. Based on the literature, the vancomycin dose for patients diagnosed with intraabdominal sepsis is $1000 \mathrm{mg}$. The administration of vancomycin by intravenous infusion at a quantity of $1 \mathrm{~g}$ should be given with a duration of administration that runs out within $>60$ minutes ( 1 hour) to prevent the side effects of rapid infusion or red-man syndrome. The administration of vancomycin to patients with intraabdominal sepsis has therefore followed the literature (Dipiro et al., 2008).

According to the study results, patients with a diagnosis of cellulitis received a dose of $1 \mathrm{~g}$ every 12 hours with a duration of administration of five days given intravenously. Based on the Diagnosis and Treatment of Cellulitis, vancomycin dosage for cellulitis is $15 \mathrm{mg} / \mathrm{kg}$ every 12 hours, so a patient weighing $82 \mathrm{~kg}$ with cellulitis should receive approximately $1230 \mathrm{mg}$. The vancomycin dose received by the patients with cellulitis in this study was below the dose set by the literature or not according to the literature.

From the study results, the patients received vancomycin at a dose of $1 \mathrm{~g}$ every 12 hours in $0.9 \% \mathrm{NaCl}$ of $100 \mathrm{cc}$, which was discharged within 1 hour given through intravenous infusion. Based on the literature, the vancomycin dosage is 1 gram every 12 hours for the diagnosis of pneumonia (Patanwala et al., 2009). Therefore, the dosage received by these patients was as per literature.

Based on the study results, the patients diagnosed with sepsis were given vancomycin at a dose of $1 \mathrm{~g}$ every 12 hours intravenously. According to the literature, the treatment using vancomycin for patients diagnosed with sepsis by MRSA culture test includes a dose of 1 g every 12 hours (Nguyen et al., 2006). Therefore, the dosage of vancomycin received by the patients for their sepsis has followed the literature.

Seminar Nasional Asosiasi Perguruan Tinggi Farmasi Indonesia (APTFI) III-Tantangan Pandemik (covid-19) dalam pembelajaran dan penelitian kefarmasian 16-20 Agustus 2021 (Virtual Conference) 
143 | Herawati, M., et al. /Jurnal Ilmiah Farmasi (Scientific Journal of Pharmacy) Special Edition 2022, 136146

From the study results, patients who received vancomycin therapy at a dose of $1 \mathrm{~g}$ every 12 hours in $\mathrm{NaCl}$ 0.9\% 100 cc by intravenous infusion were given vancomycin singly. Based on the literature, the vancomycin dosage for HAP is 1 gram every 12 hours (Patanwala et al., 2009). This indicates that the amount of vancomycin administered to the patients for their pneumonia has been in accordance with the literature.

Aminoglycoside class of antibiotics is an antibiotic that is concentration-dependent killing, and the post-antibiotic effect means the bactericidal effect of aminoglycosides is determined by the ratio between drug concentrations in plasma and MIC. The effect of bacterial killing will be optimal if the peak plasma concentration ( $\mathrm{Cmax}$ ) is > 10 times MIC of bacteria. Consequently, administration by means of the Extended Interval Aminoglycoside Dosing (EIAD) or once-daily dosing is considered more effective. Gentamicin dosage is adjusted according to the patient's kidney condition. For normal kidney function (creatinine clearance $>90 \mathrm{ml} / \mathrm{min}$ ), the empirical dosage of gentamicin should be between 1.2-2 mg/kg every 8 hours (Pangalila, 2012).

Meropenem is generally given to patients at a dose of $500 \mathrm{mg}$ - 1 gram every 8 hours. In meningitis, meropenem is provided at a dose of 2 grams every 8 hours. Adjustment of the dosage in the administration of meropenem needs to be done when the antibiotic is given to patients, infants, children, and the elderly (Lacy et al., 2009).

A large number of doses of meropenem is given to patients at 12-hour and 8-hour intervals. Patients who receive meropenem at 12-hour intervals are the elderly and patients with impaired kidney function. Meropenem requires dose adjustment in patients having a poor renal function with Clcr of less than $50 \mathrm{~mL} / \mathrm{min}$, dialysis patients, and patients taking continuous renal replacement therapy (CRRT) through an increase in the dosage interval to every 12 hours or 24 hours (Lacy et al., 2009).

Related to the duration, duration of vancomycin use in the patients was eight days, while based on the literature, vancomycin should be given to infective endocarditis for four weeks (Vandecasteele, \& De Vriese, 2010). Meanwhile, the duration of vancomycin use in the patients was seven days, and based on the literature for the benefit of vancomycin for infections caused by MRSA, it is recommended to be given for 7-14 days (Lambert, 2011); therefore, the duration of use for the patients has been appropriate. Meanwhile, based on the culture test of SWD patients given vancomycin for infections caused by MRSA bacteria, it has already been reasonable.

The duration of vancomycin use in the patients was five days, whereas based on the literature, the period of vancomycin use for patients with skin or soft tissue infections caused by MRSA bacteria is approximately 5-10 days (Raff \& Kroshinsky, 2016). The duration of vancomycin 
144 | Herawati, M., et al. /Jurnal Ilmiah Farmasi (Scientific Journal of Pharmacy) Special Edition 2022, 136146

use in S patients was therefore appropriate. The use of vancomycin in these S patients is empirical. Based on the literature, vancomycin antibiotics can be given to patients' syringes without culture testing.

The duration of use of vancomycin was eight days. Based on the literature, the service period for pneumonia caused by MRSA bacteria is 7-21 days (Lambert, 2011). Therefore, the duration of use for the patients has been in accordance with the literature. Meanwhile, patients who received vancomycin antibiotics for MRSA bacteria were appropriate for culture testing.

The duration of use for patients who received vancomycin was one day because during the first use these patients already had allergies. Based on the literature, the time of use for patients diagnosed with an infection caused by MRSA bacteria given vancomycin is for 7-14 days (Lambert, 2011).

The duration of vancomycin use in these patients was six days. Based on the literature, the duration of vancomycin use for the diagnosis of pneumonia is 7 to 21 days (Lambert, 2011). Based on the literature, the use of vancomycin antibiotics should be based on culture and sensitivity testing (Aberg et al., 2009).

Duration of administration is one of the factors that can be used to measure the effectiveness of drug use and to identify the average time of patient therapy. In table 2 , it can be seen that the duration of administration of gentamicin is seven days at most. The period of antibiotic use also shows different results depending on the infection suffered by the patient. According to the Indonesian Ministry of Health (2009), antibiotics are generally effectively used for therapy for less than ten days. Most patients are allowed to go home after receiving treatment in the hospital for less than ten days. Another study also mentions that the effective duration of antibiotic therapy is 10-14 days (Farida et al., 2017).

This study showed that patients who received the most extended antibiotic therapy for ten days were diagnosed with sepsis. In terms of indications, the use of antibiotics is appropriate. Based on the literature on patients with sepsis, 10-14 days of treatment with antibiotics is recommended (Sivanandan et al., 2011).

The shortest duration of the administration of meropenem was one day. Before being given meropenem antibiotics, these patients used ceftriaxone as their first therapy. As a result, these patients had a diagnose unrelated to infectious diseases such as pulmonary edema and after cesarean section. However, the patients' laboratory data showed an increase in the neutrophil levels to above the average of $82 \%$, while the lymphocyte levels were below the standard threshold of $10 \%$. These parameters indicated that the patients had an infection with high severity. However, the 
145 | Herawati, M., et al. /Jurnal Ilmiah Farmasi (Scientific Journal of Pharmacy) Special Edition 2022, 136146

administration of meropenem antibiotics with a short duration of concern could result in antibioticresistant bacteria.

The most extended duration of administration of meropenem was 29 days. Patients who received meropenem antibiotic therapy suffered from complications due to bronchopneumonia infection and sepsis, and these patients were diagnosed with stage IV B20 disease. Patients diagnosed with B20 are susceptible to nosocomial conditions because the disease attacks the patient's defense system. Therefore, it is necessary to administer broad-spectrum antibiotics such as meropenem. However, long-term administration of meropenem is not recommended because it can lead to fungal and bacterial superinfection, including C. difficile-associated diarrhea (CDAD) and pseudomembranous colitis (Lacy et al., 2009). In addition, the administration of antibiotics with a long duration is not recommended considering the effectiveness of therapy and the increase in the likelihood of antibiotic-resistant bacteria.

\section{Conclusion}

Vancomycin and meropenem are included in the category of retention drugs (restricted use) because these antibiotics have a high frequency of resistance. However, the use of gentamicin must also be given special attention because if there is an error in giving either an indication, dosage, or duration, it can cause a decrease in the kidney function of the patient. The results of this study indicated that the conditions were still found to be inconsistent with the indication, dosage, and duration. As with vancomycin, the use had to be based on bacterial culture data. However, none of the patients had bacterial culture data. One patient was identified as having an allergic response to vancomycin, which could worsen the patient's condition. In terms of the use of drugs or the duration, there were still some that did not comply with the antibiotic use guidelines. This would be hazardous for patients and could develop into antibiotic resistance. The dosage given to patients who received either vancomycin or gentamicin or meropenem therapy was all stated according to the dosage in the guidelines. Vancomycin, Gentamycin, and Meropenem were appropriate to the dosage, but discrepancies were still found in the indication and duration of the treatment using antibiotics.

\section{References}

Aberg, J.A., et al, 2009. Drug Information Handbook. Lexi-Comp for the American Pharmacists Association.

Ames, Iwoa, 2016. Methicillin Resistant Staphylococcus aureus. The Center for Food Security \& Public Health 1-3. 
146 | Herawati, M., et al. /Jurnal Ilmiah Farmasi (Scientific Journal of Pharmacy) Special Edition 2022, 136146

Baddour et al, 2015. Infective Endocarditis in Adults: Diagnosis, Antimicrobial Therapy, and Management of Complications. AHA Scientific Statement 132, 1435-1486. https://doi.org/10.1161/CIR.0000000000000296

Balahura, C., et al, 2015. Update In Antibiotic Therapy Of Biliary Tract Infections. Revista Romana De B Oli Infectioase 13, 38.

Brunton L., Keith Parker, Donald Blumenthal, Iain Buxton, 2008. Goodman \& Gilmans Manual of Pharmacology and Therapeutics. Mc Graw Hill Medical, New York.

Diener MK., et al, 2005. A case of methicillin-resistant Staphylococcus aureus infection following bile duct stenting. World J Gastroenterol 11, 1397.

Dipiro J.T., R. L.Talbert, G. C.Yee, G. R.Matzke, B. G. Wells, L. M. Posey, 2008. Pharmachotherapy A Pathophysiologic Approach, Sevent edition. ed. Mc Graw Hill Medical, New York.

Kemenkes RI, 2015. Peraturan Menteri Kesehatan Republik Indonesia Nomor 8 tahun 2015 tentang Program Pengendalian Resistensi Antimikroba di Rumah Sakit. Direktorat Bina Pelayanan Kefarmasian.

Kemenkes RI, 2011a. Pedoman Pelayanan Kefarmasian Untuk Terapi Antibiotik. Bina Kefarmasian dan Alat Kesehatan, Jakarta.

Lambert, M, 2011. IDSA Guidelines on the Treatment of MRSA Infections in Adults and Children. American Family Physician 84, 456-461.

Patanwala et al., 2009. Vancomycin Dosing for Pneumonia in Critically Ill Trauma Patients. The Journal of TRAUMA® Injury, Infection, and Critical Care 67, 802-804.

Radhika, et al, 2014. Pharmacokinetics of intravitreal antibiotics in endophthalmitis. Journal of Ophthalmic Inflammation and Infection 4, 2.

Raff AB., Daniela Kroshinsky, $2016 . \quad$ Cellulitis 316, 325-337. https://doi.org/10.1001/jama.2016.8825

Rizzo, JL., et al, 2012. Exogenous endophthalmitis: Post-operative versus post-intravitreal injection. Vis. Pan-America 11 (2), 42.

Shim, R., Connie H. Y. Wong, 2016. Ischemia, Immunosuppression and Infection-Tackling the Predicaments of Post-Stroke Complications. International Journal of Molecular Sciences 17. https://doi.org/0.3390/ijms17010064

Solomkin, J.S. et al., 2009. Diagnosis and Management of Complicated Intra-abdominal Infection in Adults and Children: Guidelines by the Surgical Infection Society and the Infectious Diseases Society of America. IDSA Guidline 50, 139.

Van Lunzen and Altfeld, 2014, Sex Differences in Infectious Diseases-Common but Neglected, The Journal of Infectious Diseases, Volume 209, Issue suppl_3, pS79S80.https://doi.org/10.1093/infdis/jiu159

WHO, 2015a, WHO multi-country survey reveals widespread public misunderstanding about antibiotic resistance, <available at: https://www.who.int/news/item/16-11-2015-who-multi-countrysurvey-reveals-widespread-public-misunderstanding-about-antibiotic-resistance>

WHO, 2015, Global action plan on antimicrobial resistance. WHO Library Cataloguing-in-Publication Data. WHO document production services. Geneva. Switzerland.

WHO, 2017, Global action plan on antimicrobial resistance, World Health Organization, pp. 1-28.

Seminar Nasional Asosiasi Perguruan Tinggi Farmasi Indonesia (APTFI) III-Tantangan Pandemik (covid-19) dalam pembelajaran dan penelitian kefarmasian 16-20 Agustus 2021 (Virtual Conference) 